\title{
Predicting empty body weight in growing goats: A meta-analytic approach
}

\author{
Letícia Marra Campos, Amélia Katiane Almeida, Bruno Biagioli, Kleber Tomas Resende, \\ Izabelle Auxiliadora Molina Almeida Teixeira*
}

Universidade Estadual Paulista (UNESP), Department of Animal Science, Jaboticabal, SP 14884-900, Brazil

\section{A R T I C L E I N F O}

\section{Keywords:}

Boer

Genotype

Sex

Saanen

Type of diet

\begin{abstract}
A B S T R A C T
The objective of this study was to develop statistical models to predict empty body weight (EBW) by body weight (BW), testing the influence of sex (females, intact males or castrated males), type of diet (suckling or postweaning), and genotype (Saanen, $1 / 2$ Boer $\times 1 / 2$ Saanen, 3/4 Boer $\times 1 / 4$ Saanen, and Indigenous goats). Individual records of 311 goats combined from 10 studies, with BW ranging from 4.3 to $47.4 \mathrm{~kg}$ were used. The EBW was computed as the BW at slaughter minus the weight of the contents of the digestive tract, urinary bladder, and biliary vesicle. Linear regression analyses were performed to develop the models, considering sex, type of diet, and genotype as fixed effects and random effect of study. CONTRAST statements were used to conduct all pairwise comparisons of fixed effects and all the statistical analyses were performed using SAS. The present study revealed that sex did not affect both intercept $(P=0.53)$ and slope $(P=0.19)$. On the other hand, the EBW prediction was affected by type of $\operatorname{diet}(P<0.01)$, and genotype $(P=0.02)$. Therefore, were proposed different equations to predict EBW from BW for suckling and post-weaning Saanen goats, where gastrointestinal tract content $(\mathrm{g} / \mathrm{kg} \mathrm{EBW})$ in suckling goat kids increased as they grew, oppositely it remained slightly constant in postweaning goats. The effect of genotype on the EBW:BW relationship was tested considering only post-weaning goats, and one equation was proposed for each genotype. In general, gastrointestinal tract content ( $\mathrm{g} / \mathrm{kg}$ EBW) decreased as goat kids grew in all genotypes but Indigenous goats. The results also highlighted different gastrointestinal relative capacity between genotypes. The development of these equations would enable producers and researchers to predict the animal EBW, and develop strategic plans in a goat herd.
\end{abstract}

\section{Introduction}

The decision-making in production system is often based on weight gain of the animals. In this regard, accurate body measurement of weight is crucial in assessing animal performance in vivo, and assisting the strategic management in a herd (i.e., formulating diets, reproductive management, weight gain projections, carcass yield, etc). However, in ruminants, the accuracy of the body weight (BW) measurement can be mainly affected by gastrointestinal content variation (Gionbelli et al., 2015; Meyer et al., 1960). The gastrointestinal tract (GIT) content represents from 8 up to $19 \%$ of animals' BW (Chay-Canul et al., 2014). This variation may be due to many factors: feed quality, intake level, sex, maturity degree, physiological state and evolutionary adaptations (Beranger and Robelin, 1978; Chay-Canul et al., 2014; Clauss et al., 2016; Gionbelli et al., 2015). Aiming to reduce the variation due to GIT content, Owens et al. (1995) suggested the empty body weight (EBW) should be used to better describe animal size (i.e., rather than BW). For instance, the standard method for determining the nutritional requirements in goats, (i.e., the comparative slaughter) generates EBW-based recommendations (Ferreira et al., 2015; Figueiredo et al., 2016b; Sampelayo et al., 1990; Teixeira et al., 2015).

However, the estimation of EBW is a time- and work-demanding and expensive method (Lofgreen et al., 1962), requiring the slaughter of the animal, and the digestive tract emptying. Considering that strategies management in research and production is done with live animals, it is desirable to develop models designed to make EBW usable.

Considering the wide range of factors that may affect the EBW:BW ratio, the hypothesis to be tested is that female and male goats exhibit differences in EBW:BW ratio due to differences in their growth (Burrin et al., 1992; Ferrell and Jenkins, 1998), as well as their feed intake (Ingvartsen et al., 1992; NRC, 2007). Additionally, suckling goats are functionally non-ruminants, then it is expected their GIT content would be lighter compared with post-weaning animals (Khan et al., 2011; Sampelayo et al., 1990). It is also worthy to test differences among genotype in the EBW:BW relationship because dairy breeds, would require greater intake capacity to support milk production (Backes et al., 2006), resulting in greater GIT. Thus, the objective of this meta-analytic study is to develop statistical models for the prediction of EBW by the

\footnotetext{
* Corresponding author at: Universidade Estadual Paulista (UNESP), Via de acesso Prof. Paulo Donato Castellane s/n, CEP 14884-900, Jaboticabal, Brazil.

E-mail address: izabelle@fcav.unesp.br (I.A.M.A. Teixeira).
} 
Table 1

Database and characteristics of studies included in this meta-analysis.

\begin{tabular}{|c|c|c|c|c|c|c|}
\hline Study & Reference & Genotype & Sex & Type of Diet ${ }^{\mathrm{a}}$ & Body weight range, $\mathrm{kg}$ & Number of animals \\
\hline \multirow[t]{3}{*}{1} & Almeida et al. (2015) & Saanen & Intact male & Post-weaning & $27.6-46.6$ & 14 \\
\hline & & Saanen & Castrated male & Post-weaning & $27.8-47.4$ & 16 \\
\hline & & Saanen & Female & Post-weaning & $27.4-44.9$ & 17 \\
\hline \multirow[t]{3}{*}{2} & Bompadre et al. (2014) & Saanen & Intact male & Suckling/Post-weaning & $4.7-16.6$ & 19 \\
\hline & & Saanen & Castrated male & Suckling/Post-weaning & $4.7-16.7$ & 16 \\
\hline & & Saanen & Female & Suckling/Post-weaning & $4.6-16.4$ & 18 \\
\hline 3 & Fernandes et al. (2007) & $3 / 4$ Boer $1 / 4$ Saanen & Intact male & Post-weaning & $20.2-36.6$ & 20 \\
\hline 4 & Ferreira et al. (2015) & Saanen & Castrated male & Post-weaning & $20.6-35.5$ & 27 \\
\hline 5 & Figueiredo et al. (2016a) & Saanen & Female & Post-weaning & $29.5-46.0$ & 18 \\
\hline \multirow[t]{3}{*}{6} & Figueiredo et al. (2016b) & Saanen & Intact male & Post-weaning & $15.7-34.0$ & 20 \\
\hline & & Saanen & Castrated male & Post-weaning & $15.3-32.5$ & 20 \\
\hline & & Saanen & Female & Post-weaning & $14.8-31.7$ & 18 \\
\hline 7 & Medeiros et al. (2014) & Saanen & Intact male & Suckling/Post-weaning & $5.1-21.6$ & 23 \\
\hline 8 & Resende (1989) & Indigenous & Intact male & Suckling/Post-weaning & $5.0-27.8$ & 12 \\
\hline 9 & Ribeiro (1995) & Indigenous & Intact male & Suckling/Post-weaning & $4.9-17.0$ & 14 \\
\hline \multirow[t]{2}{*}{10} & Teixeira et al. (2015) & $1 / 2$ Boer $1 / 2$ Saanen & Intact male & Suckling/Post-weaning & $4.3-16.2$ & 19 \\
\hline & & $1 / 2$ Boer $1 / 2$ Saanen & Intact male & Post-weaning & $14.6-26.3$ & 20 \\
\hline
\end{tabular}

${ }^{\text {a }}$ Post-weaning refers to studies that involved goat kids receiving just solid diet and Suckling/Post-weaning refers to studies that involved goat kids receiving milk and solid diet.

BW, testing the influence of genotype, sex, and type of diet (suckling or post-weaning).

\section{Materials and methods}

\subsection{Database}

A database of 311 individual records of body weight and empty body weight of goat kids was used. It comprised goat kids of different sexes (intact males, $n=161$; females, $n=71$; and castrated males, $n=79$ ), genotypes (Saanen, $n=226$; Boer $\times$ Saanen crossbreds: $1 / 2$ Boer $\times 1 / 2$ Saanen or $3 / 4$ Boer $\times 1 / 4$ Saanen, $n=59$, and Indigenous goats, $n=26$ ), and types of diet (suckling/post weaning, $n=121$ and post-weaning, $n=190$ ). Afterwards the suckling/post weaning goat kids will be referred as suckling. The BW of the goat kids ranged from 4.3 to $47.4 \mathrm{~kg}$. This database was combined from 10 studies (Table 1): Almeida et al. (2015), Bompadre et al. (2014), Fernandes et al. (2007), Ferreira et al. (2015), Figueiredo et al. (2016a), Figueiredo et al. (2016b), Medeiros et al. (2014), Resende (1989), Ribeiro (1995), and Teixeira et al. (2015. These studies were conducted at the Goat Facility of the Universidade Estadual Paulista (UNESP, campus of Jaboticabal, SP, Brazil; $21^{\circ} 14^{\prime} 05^{\prime \prime} \mathrm{S}$ and $48^{\circ} 17^{\prime} 09^{\prime \prime} \mathrm{W}$, altitude $595 \mathrm{~m}$ ). Animals were fed similar diets under ad libitum regimen, diets (DM basis\% \pm SD) were comprised of dehydrated corn plant ( $46.6 \pm 0.57 \%$ ) or grass hay (41.7 \pm 24.0\%; studies 5, 8, and 9), corn grain (29.6 $\pm 7.9 \%$ ), soybean meal $(17.5 \pm 3.7 \%)$, soybean oil $(1.1 \pm 0.46 \%)$, wheat bran (9.0\%; study 5), molasses ( $4.3 \pm 0.09 \%$; studies $2,3,4,7$, and 10 ), mineral supplement $(3.0 \pm 1.1 \%)$, and ammonium chloride $(0.5 \pm 0.57 \%$; studies 5 and 6$)$. For further details regarding diets within studies see supplementary material. All experimental procedures were followed in accordance with the University's Animal Care Committee, under protocols described in the published sources.

\subsection{Slaughter procedures}

All studies adopted similar slaughter procedures and chemical analyses. The animal's BW was recorded immediately before the slaughter; for those studies that adopted fasting before slaughter, it was used the BW recorded in the previous day, before fasting (studies 3, 4, 5, 7, 8, 9, and 10; Table 1). At slaughter, animals were stunned with a captive bolt pistol, followed by severing of the jugular vein and carotid artery. Blood and organs were collected and weighed. The digestive tract was weighed full and empty. The EBW was computed as the BW at slaughter minus the weight of the contents of the digestive tract, urinary bladder, and biliary vesicle.

\subsection{Statistical analyses}

Linear regression analyses (Eq. (1)) were performed to develop the models, considering sex (intact males, castrated males, and females), genotype (Saanen, $1 / 2$ Boer $\times 1 / 2$ Saanen, 3/4 Boer $\times 1 / 4$ Saanen, and Indigenous goats), and types of diet (suckling and post-weaning) as fixed effects and random effect of study. The variance due to study was considered using the RANDOM statement of MIXED procedure in SAS while fitting the regression equations (St-Pierre, 2001).

$Y_{\mathrm{ijk}}=\beta_{O \mathrm{i}}+\beta_{1 \mathrm{j}} \times B W_{\mathrm{ijk}}+s_{\mathrm{j}}+e_{\mathrm{ijk}}$

In which, $Y_{i j k}$ is the EBW $(\mathrm{kg})$ for the $\mathrm{k}^{\text {th }}$ goat of the $\mathrm{i}^{\text {th }}$ level of tested fixed effect in the $j^{\text {th }}$ study, $\beta_{0}$ and $\beta_{1}$ are the parameters to be estimated for each of the $i^{\text {th }}$ level of tested fixed effect (i.e., $i=1,2,3$ sexes, $\mathrm{i}=1,2$ types of diet or $\mathrm{i}=1,2,3$, 4 genotypes), $\mathrm{s}_{\mathrm{j}}$ is the random effect of the $\mathrm{j}^{\text {th }}$ study $\sim \mathrm{N}\left(0, \sigma_{\mathrm{s}}{ }^{2}\right)$, and $\mathrm{e}_{\mathrm{ijk}}$ is the residual error $\sim \mathrm{N}\left(0, \sigma^{2}\right)$.

If the linear regressions slope differed between suckling and postweaning Saanen goats, a segmented model (i.e., broken line, Eqs. (2) and (3)) was used to identify the BW in which the slope changed (i.e., breakpoint; Ryan and Porth, 2007).

$E B W=\beta_{0}+\beta_{1} \times B W ;$ for $B W \leq \beta_{2}$

$E B W=\left[\beta_{0}+\beta_{2} \times\left(\beta_{1}-\beta_{3}\right)\right]+\beta_{3} \times B W ;$ for $B W \leq \beta_{2}$

In which; $E B W$ is the empty body weight in $\mathrm{kg}, \beta_{0}$ and $\beta_{1}$ are, respectively, the intercept and slope of linear fit to data below breakpoint, $\beta_{2}$ is the breakpoint (i.e., the point in which the slope change), and $\beta_{3}$ is the slope of the linear fit to data above breakpoint.

In this case, the variance due to study was considered at the RANDOM statement of PROC MIXED, as explained by Almeida et al. (2016), generating an adjusted database before fitting the segmented model using PROC NLIN (see supplementary material for further details). The MARQUARDT convergence method was used, and the HOUGAARD option was requested to generate skewness values (Hougaard 1982, 1985).

When sex, type of diet or genotype was found significant $(P<0.10)$, indicating a different intercept for at least one of tested fixed effects, CONTRAST statements were used to conduct all pairwise comparisons of fixed effects. Likewise, CONTRAST statements were used to conduct all pairwise comparisons when the interaction between fixed and regressor effects was found to be significant $(P<0.10)$, indicating a different slope for at least one of the tested interaction. The statistical analyses were performed using SAS (SAS Institute Inc., Cary, NC 9.4). 
Table 2

Descriptive statistics of the database used to test the effect of sex and type of diet on parameters estimates of the linear regression of EBW by BW.

\begin{tabular}{llllll}
\hline Item $^{\text {a }}$ & $n$ & Mean & SD & Minimum & Maximum \\
\hline BW, kg & 226 & 24.1 & 12.2 & 4.60 & 47.4 \\
EBW, kg & 226 & 19.9 & 10.4 & 3.50 & 40.1 \\
DMI, \% BW & 74 & 3.43 & 0.699 & 2.01 & 5.11 \\
Age, d & 213 & 170 & 117 & 8 & 585 \\
GIT content, \% BW & 226 & 17.2 & 4.67 & 4.48 & 30.4 \\
\hline
\end{tabular}

${ }^{\mathrm{a}} \mathrm{BW}=$ Body $\quad$ weight; $\quad$ EBW $=$ Empty $\quad \mathrm{BW} ; \quad$ DMI $=$ Dry $\quad$ matter $\quad$ intake; GIT $=$ gastrointestinal tract.

\section{Results}

This meta-analysis revealed that sex did not affect both intercept $(P=0.53)$ and slope $(P=0.19)$ of the linear regression of EBW by BW. However, this relationship changed according to the type of diet $(P<0.01)$ and genotype $(P=0.02)$. Therefore, different equations for suckling and post-weaning animals were estimated. Similarly, equations to predict the EBW by BW information according to the genotype of the goats were proposed.

\subsection{BW:EBW relationship by type of diet}

To build a more robust model depicting the effect of type of diet on the linear regression of EBW by BW a database composed exclusively by Saanen goats was used (studies 1, 2, 4, 5, 6, and 7; Table 1; $n=226$ ). This decision was based on the fact that we did not have females of Boer crossbred and Indigenous goat kids, averting us to make comparisons and generate a solid model. Goat kids in this database were consuming liquid and solid diet, or only solid diet throughout the experiment. The EBW of Saanen goats weighing from 4.6 to $47.4 \mathrm{~kg}$ of BW varied from 3.5 to $40.1 \mathrm{~kg}$ (Table 2).

The results showed that the effect of type of diet in the linear regression of EBW by BW is relevant, in both intercept $(P=0.0049)$ and slope $(P=0.0035)$. It was also found that the intercept of the linear regression of EBW by BW did not differ from zero $(P=0.77$; i.e., one may decide not to consider the intercept while predicting EBW). Hence, distinct equations to estimate the EBW by BW are proposed (Fig. 1; $\left.P<0.01 ; \sigma_{\mathrm{e}}^{2}=1.196 ; \sigma_{\mathrm{s}}^{2}=0.691\right)$.

While using a segmented model to depict the change in response (i.e., EBW prediction) across BW of Saanen goats from 4.6 to $47.4 \mathrm{~kg}$, it was possible to identify that the change in slope occurred at $21.4 \pm 2.28 \mathrm{~kg}$ BW (i.e., breakpoint, Table 3). In this regard, the slope of suckling goats was $0.778 \pm 0.0170$, while the slope of post-weaning

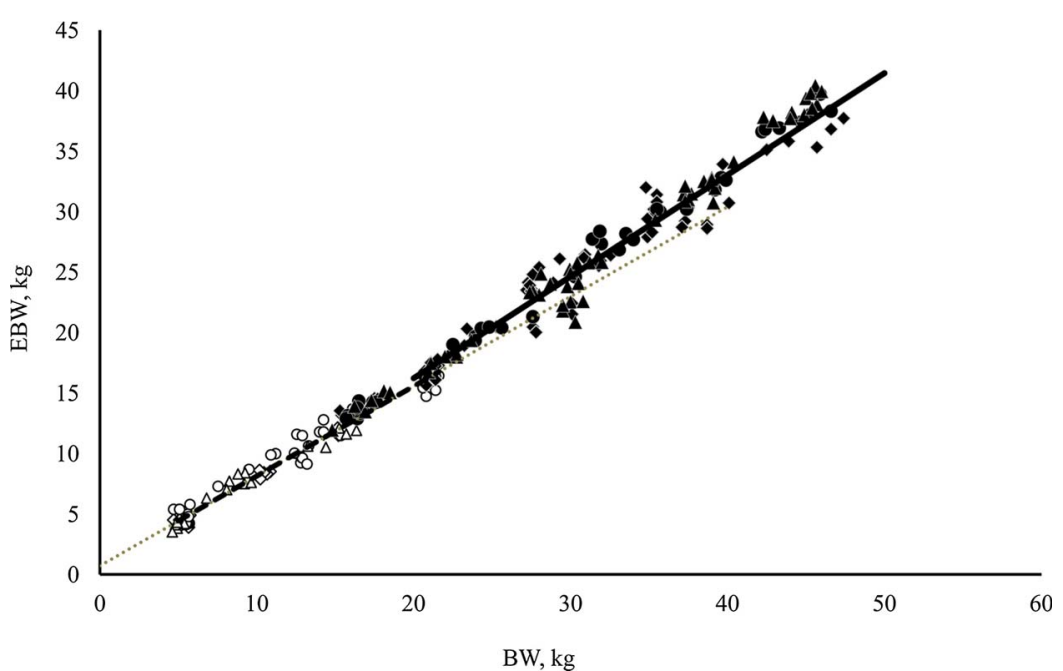

Table 3

Parameter estimates of the segmented model to describe the relationship between BW and EBW of suckling and post-weaning Saanen goats.

\begin{tabular}{|c|c|c|c|c|c|}
\hline \multicolumn{2}{|c|}{ Parameter estimates ${ }^{a}$} & \multirow{2}{*}{$\begin{array}{l}\text { S.E. } \\
0.241\end{array}$} & \multirow{2}{*}{$\begin{array}{c}{\text { Lower } \mathrm{CI}^{\mathrm{b}}}^{-0.019} \\
\end{array}$} & \multirow{2}{*}{$\begin{array}{l}\text { Upper } \mathrm{CI}^{\mathrm{c}} \\
0.929\end{array}$} & \multirow{2}{*}{$\begin{array}{l}\text { Hougaard statistics } \\
0.124\end{array}$} \\
\hline$\beta_{0}$ & 0.455 & & & & \\
\hline$\beta_{1}$ & 0.778 & 0.0170 & 0.744 & 0.811 & 0.115 \\
\hline$\beta_{2}$ & 21.4 & 2.28 & 16.9 & 25.9 & 0.130 \\
\hline$\beta_{3}$ & 0.885 & 0.0122 & 0.861 & 0.909 & 0.152 \\
\hline
\end{tabular}

a $\beta_{0}$ and $\beta_{1}$ are, respectively, the intercept and slope of linear fit to data below breakpoint, $\beta_{2}$ is the breakpoint, and $\beta_{3}$ is the slope of linear fit to data above breakpoint $\left(\mathrm{P}<0.01 ; \sigma_{\mathrm{e}}^{2}=0.943\right)$.

b Lower approximate $95 \%$ confidence limit of the parameter estimates.

${ }^{\mathrm{c}}$ Upper approximate $95 \%$ confidence limit of the parameter estimates.

goats was $0.885 \pm 0.0122$ (Table 3 ), both values are consistent with slope estimates reported while fitting different linear regression equations for each type of diet (Fig. 1). The intercept estimated of the segmented model $(0.455 \pm 0.241)$, did not differ from zero (i.e., the $95 \%$ confidence intervals overlapped zero), as well as in the linear regression equation presented for suckling goats (Fig. 1).

\subsection{BW:EBW relationship by genotype}

Data from suckling goats were not considered to depict the effect of genotype in the analysis $(n=190)$. The goats used to test the effect of genotype weighed from 13.3 to $47.4 \mathrm{~kg}$ BW, with EBW varying from 10.5 to $40.4 \mathrm{~kg}$ (Table 4). The GIT content ranged from 4.9 to $28.7 \%$ $\mathrm{BW}$, the dry matter intake (DMI) of these goats was up to $5.5 \% \mathrm{BW}$ (Table 4).

The effect of genotype in the linear regression of EBW by BW was found to be relevant, affecting both intercept $\left(\beta_{0} ; P=0.0182\right)$ and slope $\left(\beta_{1} ; \mathrm{P}=0.0119\right)$, indicating that, at least two genotype equations differed from the other (Eq. (4)-(7); $P<0.01 ; \sigma_{\mathrm{e}}^{2}=1.102$; $\left.\sigma_{\mathrm{s}}^{2}=0.013\right)$.

$E B W_{\text {Saanen }}=-1.87( \pm 0.359)+0.887( \pm 0.0114) \times B W$
$E B W_{1 / 2 \text { Boer }} \times{ }_{1 / 2 \text { Saanen }}=-0.804( \pm 1.165)+0.803( \pm 0.0531) \times B W$

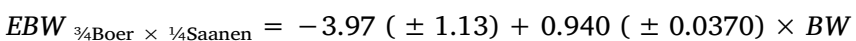

$E B W_{\text {Indigenous }}=1.66( \pm 1.43)+0.72( \pm 0.0679) \times B W$

In which, $E B W$ is the empty body weight $(\mathrm{kg})$ and $B W$ is the body weight $(\mathrm{kg})$.

The intercept of $1 / 2$ Boer $\times 1 / 2$ Saanen and Indigenous genotypes did

Fig. 1. Relationship between BW and EBW of suckling (open symbols and dotted black line) and post-weaning (closed symbols and continuous black line) Saanen goats (circles represents observations of intact males, diamonds represents observations of castrated males and triangles represents observations of females). Fitted equations ( $\mathrm{P}<0.01 ; \sigma_{\mathrm{e}}^{2}=1.196$; $\left.\sigma_{\mathrm{s}}^{2}=0.691\right)$ dotted black line: $E B W_{\text {suckling }}=0.714( \pm 0.351)+0.742$ $( \pm 0.032) \times B W$; continuous black line: $E B W$ post-weaning $=-0.608$ $( \pm 0.305)+0.841( \pm 0.0093) \times B W$; in which, $B W$ is the body weight $(\mathrm{kg})$ and $E B W$ is the empty body weight $(\mathrm{kg})$. 
Table 4

Descriptive statistics of the database used to test the effect of genotype on parameters estimates of the linear regression of EBW by BW.

\begin{tabular}{llllll}
\hline Item $^{\text {a }}$ & $n$ & Mean & SD & Minimum & Maximum \\
\hline BW, kg & 232 & 27.3 & 9.39 & 13.3 & 47.4 \\
EBW, kg & 232 & 22.3 & 8.28 & 10.5 & 40.4 \\
DMI, \% BW & 98 & 3.61 & 0.758 & 2.01 & 5.47 \\
Age, d & 215 & 186 & 103 & 54 & 585 \\
GIT content, \% BW & 232 & 18.7 & 4.29 & 4.86 & 28.7 \\
\hline
\end{tabular}

${ }^{\mathrm{a}} \mathrm{BW}=$ Body $\quad$ weight $\quad$ EBW $=$ Empty $\quad$ BW; $\quad$ DMI $=$ Dry $\quad$ matter $\quad$ intake; GIT $=$ gastrointestinal tract.

not differ from zero ( $P=0.49$ and $P=0.25$, respectively). The intercept $(P=0.12)$ neither the slope $(P=0.14)$ of $1 / 2$ Boer $\times 1 / 2$ Saanen differed from Saanen goats estimated parameters, indicating similarities among these genotypes. The same pattern was observed when comparing the intercept and slope of the regression equation of $1 / 2$ Boer $\times 1 / 2$ Saanen goats, with Indigenous goats $(P=0.18$ and $P=0.31$; respectively). Because the parameter estimates are correlated amongst them, it is recommended one equation to estimate EBW from BW for each genotype of post-weaning goats, regardless similarities. In general, GIT content ( $\mathrm{g} / \mathrm{kg}$ EBW) decreased as goat kids grew in all genotypes except for Indigenous goats. The results demonstrated that GIT content ( $\mathrm{g} / \mathrm{kg}$ EBW) of Indigenous goats increased as they grew.

\section{Discussion}

This meta-analysis enabled to verify the effect of sex, type of diet and genotype in the regression equation of EBW by BW in growing goats. In summary, the results revealed that the regression equation to estimate the EBW by BW did not change with sex. On the other hand, distinct regression equations were proposed of EBW by BW depending on type of diet and genotype.

The absence of sex effect was not expected once as an animal grows, the body favors fat deposition during positive energy balance. Sex would shape the pattern of energy deposition in the body in a way that the fatness degree of females tends to be greater than males. It has been proposed that fat depot signals to central neural-system lead to DMI depression (i.e., lipostatic theory; Ingvartsen and Boisclair, 2001). A hormone that can act in this process is leptin, which is secreted by adipose tissue and its concentration is directly related to the proportion of body fat. When its level increases, the intake decreases due to inhibition of secretion in the neuropeptide $\mathrm{Y}$, important ingestion stimulator, by the hypothalamus (Maggioni et al., 2009). Also, it was proposed that intact males would have greater DMI compared to castrated males and females, due to their greater maintenance requirements (NRC, 2007) and weight gain (Aregheore, 1995; Rodríguez et al., 2008). In contrast, previous studies also reported absence of sex effect on DMI (Kirland et al., 2006; Marcondes et al., 2008). Among the set of published studies used in the present meta-analysis, in which sex effect was evaluated, none of them found sex effect on DMI, nor on energy maintenance requirements in growing goats (Almeida et al., 2015; Bompadre et al., 2014; Figueiredo et al., 2016b). In this sense, the hypothesis that differences in the growth pattern of the goats would lead to distinct DMI, which by its turn could affect the EBW prediction equations is rejected.

In general, this study showed that GIT content ( $\mathrm{g} / \mathrm{kg}$ EBW) in suckling goat kids increased as they grew, ranging from $13 \%$ to $27 \%$ EBW. This occurred because the rumen is a retaining compartment and it is expected rumen retains more feed as the animal grows, contributing to the GIT contents increase. On the other hand, with postweaning goats the results showed opposite pattern, where GIT content ( $\mathrm{g} / \mathrm{kg}$ EBW) remained almost constant as goat kids grew, decreasing from $25 \%$ to $21 \%$ EBW. During early post-natal period, ruminants' digestion is highly dependent on abomasum and intestines' activity to fulfill demands of the animal to assimilate maternal milk (Drackley, 2008; Morisset, 1993). At this period, rumen-reticulum has a low development and is not fully functional, comprising about $30 \%$ of the total GIT (Li et al., 2012; Lima et al., 2013). As ruminant ages, the capacity of the GIT compartments changes in response to shifts in the type and form of supplied feed (Baldwin et al., 2004; Carvalho et al., 2003). During the transition from non-functional ruminant to ruminant until weaning, there is an intense ruminal development (Amaral et al., 2005), followed by a deceleration in development of abomasum (Lima et al., 2013). These changes result in increased weight of the rumen itself, and also in its capacity to carry digestion. Transitioning goats exhibit rumen weight increase as a result of microbiota colonization, the metabolic products of ruminal microbes, and diet (Li et al., 2012).

The observed GIT content variation of 4.5 up to $30.4 \%$, which may be a result of the observed variation of dry matter intake (from 2.0 to $5.1 \%$ BW; Table 2), among other factors. In this regard, the most striking weight changes in the GIT in transitional goats are associated with the rumen development, however changes in intestinal weight also occurs in response to dietary changes (Baldwin et al., 2004). While other organs decline (i.e., percentage of EBW) as the ruminant matures, the rumen increases from about 40 up to $80 \%$ of the capacity of the whole forestomach (Warner et al., 1956). For instance, the point of change is $21.4 \pm 2.28 \mathrm{~kg}$ BW (i.e., breakpoint, Table 3) for Saanen goats under nutritional management similar to adopted in this study. In this sense, building a unique equation including all Saanen goats (i.e., suckling and post-weaning) would bias the prediction of EBW in postweaning goats (see dotted gray line in Fig. 1), underestimating the EBW in heavier ones. Thus, it was proposed an equation aiming to predict EBW by BW in suckling growing Saanen goats, a distinct equation to predict EBW of post-weaning goats and a segmented model with the same principle and aim. In this regard, both approaches were very consistent between them; the segmented model showed slightly lower variance of the error $\left(\sigma_{\mathrm{e}}^{2}=0.943\right)$ than the linear regressions $\left(\sigma_{\mathrm{e}}^{2}=1.196\right)$, one may think that the segmented model is biologically more realistic, however both would yield similar predictions and accuracy.

It is worthy to point out that, the effect of early and late weaning managements should be investigated. Because the weaning management of goats, which composed the database herein used, was similar (i.e., kids were weaned around $12 \mathrm{~kg}$ BW and $50 \mathrm{~d}$ of age), it was not possible to depict the effect of weaning management on EBW:BW relationship. One can observe that this transition period to gain full rumen functionality may be long, indicated by the wide $95 \%$ confidence interval of the breakpoint (from 16.9 up to $25.9 \mathrm{~kg} \mathrm{BW}$, Table 3).

Inherent intake capacity of goat breeds due to growth patterns and production aptitude would justify the need of one equation to predict EBW for each of tested genotypes presented in the results. For instance, Fernandes et al. (2017) reported the DMI in Anglo Nubian goats (i.e., dual-purpose breed) to be $54 \%$ greater per kg BW compared to Saanen goats (i.e., dairy breed). Even among dairy breeds, Härter et al. (2015) found that Saanen goats had greater DMI (average $56.8 \mathrm{~g} / \mathrm{kg}$ BW daily) compared to Oberhasli goats (average $38.8 \mathrm{~g} / \mathrm{kg}$ BW daily). In addition, previous study showed that genetic percentage of Boer contribution in the crossbred would affect DMI and also digestibility of dry matter (Tilahun et al., 2014). These animals usually have lower metabolic rates, which results in lower maintenance requirements (NRC, 2007).

The nutrient requirement to support maintenance and milk production results in heavier GIT in specialized dairy breeds (Peron et al., 1993). Conversely, meat goats were selected for greater muscular growth, what would dilute their GIT proportional size. It is worth to point out that the visceral tissue (which includes the GIT) consumes up to $50 \%$ of the required energy for maintenance (Huntington, 1990), while protein synthesis represents barely 23\% (Seal and Reynolds, 1993). In this sense, Garrett (1971) reported that dairy cows required $5 \%$ more feed for maintenance compared with beef cattle. Adaptability 
of Boer goats has been reviewed (Casey and Van Niekerk, 1988), which includes drought resistance, tolerance of tannins, efficient fiber digestion, adaptation to various ambient temperature, and lower water turnover rate, which can be explained by evolutionary pressure. Boer goats show fast growing rates (average daily gains of $200 \mathrm{~g}$; Gurung and Solaiman, 2010). Boer goat kids fed for $200 \mathrm{~g} / \mathrm{d}$ of average daily gain require $120 \mathrm{~g}$ of metabolizable protein (MP) per day compared with dairy and Indigenous goat kids at the same BW, which requires $97 \mathrm{~g} / \mathrm{d}$ of MP (i.e., considering a goat weighing $30 \mathrm{~kg} \mathrm{BW;} \mathrm{NRC,} \mathrm{2007).} \mathrm{Like-}$ wise, the NRC (2007) also recommended distinct energy requirements taking into consideration the genotype: the metabolizable energy for maintenance $\left(\mathrm{ME}_{\mathrm{m}}\right)$ of a dairy kid is $139 \mathrm{kcal} / \mathrm{kg} \mathrm{BW}{ }^{0.75}$, while meat and Indigenous goats require around $16 \%$ less $\mathrm{ME}_{\mathrm{m}}$. The metabolizable energy for gain $\left(\mathrm{ME}_{\mathrm{g}}\right)$ of meat and dairy goats reported by the NRC (2007) is $17 \%$ greater than $\mathrm{ME}_{\mathrm{g}}$ recommended for Indigenous goats (i.e., $4.73 \mathrm{kcal} / \mathrm{g}$ BW gain). In this regard, DMI would also differ among genotypes to support their growth potential. In fact, Luo et al. (2004) proposed distinct equations aiming to predict DMI in goats. The different intake potentials coupled with different carcass weight among genotypes may change the EBW:BW relationship in goats.

All in all, the present study would assist producers and researchers to overcome mistakes in growing goat's size estimations due to the variation of GIT content.

\section{Conclusion}

The study indicated that the models to predict empty body weight by body weight are dependent on the type of diet as well as genotype. Females, intact and castrate males growing Saanen goats have similar EBW:BW relationship. The change in the EBW:BW relationship for Saanen goats may be associated with the rumen development.

\section{Acknowledgments}

Authors are thankful to São Paulo Research Foundation (FAPESP) for financial support (grants \# 2014/14734-9, 2015/14091-3).

\section{Appendix A. Supplementary data}

Supplementary data associated with this article can be found, in the online version, at http://dx.doi.org/10.1016/j.smallrumres.2017.09. 002.

\section{References}

Almeida, A.K., Resende, K.T., St-Pierre, N., Silva, S.P., Soares, D.C., Fernandes, M.H.M.R., Souza, A.P., Silva, N.C.D., Lima, A.R.C., Teixeira, I.A.M.A., 2015. Energy requirements for growth in male and female Saanen goats. J. Anim. Sci. 93, 3932-3940.

Almeida, A.K., Resende, K.T., Tedeschi, L.O., Fernandes, M.H.M.R., Regadas Filho, J.G.L., Teixeira, I.A.M.A., 2016. Using body composition to determine weight at maturity of male and female Saanen goats. J. Anim. Sci. 94, 2564-2571.

Amaral, C.M.C., Sugohara, A., Resende, K.T., Machado, M.R.F., Cruz, C., 2005 Performance and ruminal morphologic characteristics of Saanen kids fed ground: pelleted or extruded total ration. Small Rumin. Res. 58, 47-54

Aregheore, E.M., 1995. Effect of sex on growth rate, voluntary feed intake and nutrient digestibility of West African Dwarf goats fed crop residue rations. Small Rumin. Res. 15, 217-221.

Backes, A.A., Paulino, M.F., Alves, D.D., Rennó, L.N., Valadares Filho, S.C., Lana, R.P., 2006. Tamanho relativo dos órgãos internos e do trato gastrintestinal de bovinos Zebu e mestiços leiteiros em sistema de recria. Cienc. Rural 36, 594-598.

Baldwin, R.L., Mcleod, K.R., Klotz, J.L., Heitmann, R.N., 2004. Rumen development, intestinal growth and hepatic metabolism in the pre-and post-weaning ruminant. J. Dairy. Sci. 87, E55-E65.

Beranger, C., Robelin, J., 1978. Estimation du poids du contenu digestif des bovins à partir du poids du contenu du rumen. Ann. Zootech. 27, 639-645.

Bompadre, T.F.V., Boaventura Neto, O., Mendonça, A.N., Souza, S.F., Oliveira, D., Fernandes, M.H.M.R., Harter, C.J., Almeida, A.K., Resende, K.T., Teixeira, I.A.M.A. 2014. Energy requirements in early life are similar for male and female goat kids. Asian-Austral. J. Anim. Sci. 27, 1712-1720.

Burrin, D.G., Britton, R.A., Ferrell, C.L., Bauer, M.L., 1992. Level of nutrition and visceral organ protein synthetic capacity and nucleic acid content in sheep. J. Anim. Sci. 70, 1137-1145.
Carvalho, P.A., Sanchez, L.M.B., Viégas, J., Velho, J.P., Jauris, G.C., Rodrigues, M.B., 2003. Componentes do peso vivo e órgãos viscerais de bezerros machos de origem leiteira ao nascimento, 50 e 110 dias de vida. R. Bras. Zootec. 32, 1469-1475.

Casey, N.H., Van Niekerk, W.A., 1988. The Boer Goat. I. Origin, adaptability, performance testing, reproduction and milk production. Small Rumin. Res. 1, 291-302.

Chay-Canul, A.J., Espinoza-Hernandez, J.C., Ayala-Burgos, A.J., Magaña-Monforte, J.G., Aguilar-Perez, C.F., Chizzotti, M.L., Tedeschi, L.O., Ku-Vera, J.C., 2014. Relationship of empty body weight with shrunken body weight and carcass weights in adult Pelibuey ewes at different physiological states. Small Rumin. Res. 117, 10-14.

Clauss, M., Stewart, M., Price, E., Peilon, A., Savage, T., Van Ekris, I., Munn, A., 2016. The effect of feed intake on digesta passage, digestive organ fill and mass, and digesta dry matter content in sheep (Ovis aries): Flexibility in digestion but not in water reabsorption. Small Rumin. Res. 138, 12-19.

Drackley, J.K., 2008. Calf nutrition from birth to breeding. Vet. Clin. North Am. Food Anim. Pract. 24, 55-86.

Fernandes, M.H.M.R., Resende, K.T.D., Tedeshi, L.O., Fernandes, J.S., Silva, H.M., Carstens, G.E., Berchielli, T.T., Teixeira, I.A.M.A., Akinaga, L., 2007. Energy and protein requirements for maintenance and growth of Boer crossbred kids. J. Anim. Sci. 85, 1014-1023.

Fernandes, M.H.M.R., Lima, A.R.C., Almeida, A.K., Borghi, T.H., Teixeira, I.D.A., Resende, K.T., 2017. Fasting heat production of Saanen and Anglo Nubian goats measured using open-circuit facemask respirometry. J. Anim. Physiol. Anim. Nutr. 101, 15-21.

Ferreira, A.C.D., Yáñez, E.A., Medeiros, A.N., Resende, K.T., Pereira Filho, J.M., Fernandes, M.H.M.R., Almeida, A.K., Teixeira, I.A.M.A., 2015. Protein and energy requirements of castrated male Saanen goats. Small Rumin. Res. 123, 88-94.

Ferrell, C.L., Jenkins, T.G., 1998. Body composition and energy utilization by steers of diverse genotypes fed a high-concentrate diet during the finishing period: II Angus, Boran, Brahman, Hereford, and Tuli sires. J. Anim. Sci. 76, 647-657.

Figueiredo, F.O.M., Berchielli, T.T., Resende, K.T., Gomes, H.F.B., Almeida, A.K., Sakomura, N.K., Teixeira, I.A.M.A., 2016a. Energy requirements for growth of pubertal female Saanen goats. J. Anim. Physiol. Anim. Nutr. 100, 294-300.

Figueiredo, F.O.M., Leite, R.F., St-Pierre, N.R., Resende, K.T., Almeida, A.K., Souza, A.P., Teixeira, I.A.M.A., 2016b. Energy and protein requirements of weaned male and female Saanen goats. J. Anim. Physiol. Anim. Nutr. http://dx.doi.org/10.1111/jpn. 12539.

Garrett, W.N., 1971. Energetic efficiency of beef and dairy steers. J. Anim. Sci. 32, 451-456.

Gionbelli, M.P., Duarte, M.S., Valadares Filho, S.C., Detmann, E., Chizzotti, M.L., Rodrigues, F.C., Zanetti, D., Gionbelli, T.R.S., Machado, M.G., 2015. Achiving body weight adjustments for feeding status and pregnant or non-pregnant condition in beef cows. PLoS One 10, e0112111.

Gurung, N.K., Solaiman, S.G., 2010. Goat breeds. In: Solaiman, S.G. (Ed.), Goat Science and Production. Blackwell Publishing, Ames, Iowa, pp. 21-32.

Härter, C.J., Castagnino, D.D.S., Rivera, A.R.D., Lima, L.D.D., Silva, H.G.D.O., Mendonça, A.N., Teixeira, I.A.M.A., 2015. Mineral metabolism in singleton and twin-pregnant dairy goats. Asian Australas. J. Anim. Sci. 28, 37-49.

Hougaard, P., 1982. Parametrizations of non-linear models. J. R. Stat. Soc. Series B Stat. Methodol. 244-252.

Hougaard, P., 1985. Saddlepoint approximations for curved exponential families. Stat. Probab. Lett. 3, 161-166.

Huntington, G.B., 1990. Energy metabolism in the digestive tract and liver of cattle: influence of physiological state and nutrition. Reprod. Nutr. Dev. 30, 35-47.

Ingvartsen, K.L., Boisclair, Y.R., 2001. Leptin and the regulation of food intake energy homeostasis, and immunity with special focus on periparturient ruminants. Domest. Anim. Endocrinol. 21, 215-250.

Ingvartsen, K.L., Andersen, H.R., Foldager, J., 1992. Effect of sex and pregnancy on feed intake capacity of growing cattle. Acta Agric. Scand. A 42, 40-46.

Khan, M.A., Weary, D.M., Von Keyserlingk, M.A.G., 2011. Invited review: effects of milk ration on solid feed intake, weaning, and performance in dairy heifers. J. Dairy. Sci. 94, 1071-1081.

Kirland, R.M., Keady, T.W.J., Patterson, D.C., Kilpatrick, D.J., Steen, R.W.J., 2006. The effect of slaughter weight and sexual status on performance characteristics of male Holstein-Friesian cattle offered a cereal-based diet. Anim. Sci. 82, 397-404.

Li, R.W., Connor, E.E., Li, C., Baldwin, V.I., Ransom, L., Sparks, M.E., 2012. Characterization of the rumen microbiota of pre-ruminant calves using metagenomic tools. Environ. Microbiol. 14, 129-139.

Lima, P.O., Lima, R.N., Miranda, M.V.F.G., Pereira, M.W.F., Azevedo Melo, F. B., Cordeiro, L.A.V., Assis, A.P.P., Souza Leite, H.M., 2013. Desenvolvimento dos estômagos de bezerros recebendo diferentes dietas líquidas. Cienc. Rural 43, 716-721.

Lofgreen, G.P., Hull, J.L., Otagaki, K.K., 1962. Estimation of empty body weight of beef cattle. J. Anim. Sci. 21, 20-24.

Luo, J., Goetsch, A.L., Nsahlai, I.V., Moore, J.E., Galyean, M.L., Johnson, Z.B., Sahlu, T., Ferrell, C.L., Owens, F.N., 2004. Voluntary feed intake by lactating, Angora, growing and mature goats. Small Rumin. Res. 53, 357-378.

Maggioni, D.A.M.J., Rotta, P.P., Zawadzki, F., Ito, R.H., Prado, I.N., 2009. Ingestão de alimentos. Semin. Ciênc. Agrár. 30, 963-974.

Marcondes, M.I., Valadares Filho, S.D.C., Paulino, P.V.R., Detmann, E., Paulino, M.F., Diniz, L.L., Santos, T.R., 2008. Consumo e desempenho de animais alimentados individualmente ou em grupo e características de carcaça de animais Nelore de três classes sexuais. R. Bras. Zootec. 37, 2243-2250.

Medeiros, A.N., Resende, K.T., Teixeira, I.A.M.A., Araújo, M.J., Yañez, E.A., Ferreira, A.C., 2014. Energy requirements for maintenance and growth of male Saanen goat kids. Asian-Austral. J. Anim. Sci. 27, 1293-1302.

Meyer, J.H., Lofgreen, G.P., Gareett, W.N., 1960. A proposed method for removing sources of error in beef cattle feeding experiments. J. Anim. Sci. 19, 1123-1131.

Morisset, J., 1993. Regulation of growth and development of the gastrointestinal tract. J. 
Dairy Sci. 76, 2080-2093.

NRC, 2007. Nutrient Requirements of Small Ruminants: Sheep, Goats, Cervids, and New World Camelids. National Academies Press, Washington, DC, USA.

Owens, F.N., Gill, D.R., Secrist, D.S., Coleman, S.W., 1995. Review of some aspects of growth and development of feedlot cattle. J. Anim. Sci. 73, 3152-3172.

Peron, A.J., Fontes, C.A.A., Lana, R.P., Silva, D.J., Queiroz, A.C., Paulino, M.F., 1993. Tamanho de órgãos internos e distribuição da gordura corporal, em novilhos de cinco grupos genéticos, submetidos à alimentação restrita e ad libitum. R. Bras. Zootec. 22, 813-819.

Resende, K.T., 1989. Métodos de estimativa da composição corporal e exigências nutricionais de proteína, energia e macrominerais inorgânicos de caprinos em crescimento. Doctorate Thesis. Universidade Federal de Viçosa, Viçosa, Brazil.

Ribeiro, S.D.A., 1995. Composição corporal e exigências em energia, proteína e macrominerais de caprinos mesticos em fase inicial de crescimento. Doctorate Thesis. Universidade Estadual Paulista (UNESP), Jaboticabal, Brazil.

Rodríguez, A.B., Bodas, R., Prieto, N., Landa, R., Mantecón, A.R., Giráldez, F.J., 2008. Effect of sex and feeding system on feed intake growth, and meat and carcass characteristics of fattening Assaf lambs. Livest. Prod. Sci. 116, 118-125.
Ryan, S.E., Porth, L.S., 2007. A tutorial on the piecewise regression approach applied to bedload transport data. General Technical Report RMRS-GTR-189. Department of Agriculture, Forest Service, Rocky Mountain Research Station, Fort Collins, CO.

Sampelayo, M.R., Ruiz, I., Gil, F., Boza, J., 1990. Body composition of goat kids during sucking. Voluntary feed intake. Br. J. Nutr. 64, 611-617.

Seal, C.J., Reynolds, C.K., 1993. Nutritional implications of gastrointestinal and liver metabolism in ruminants. Nutr. Res. Rev. 6, 185-208.

St-Pierre, N.R., 2001. Invited review: integrating quantitative findings from multiple studies using mixed model methodology. J. Dairy Sci. 84, 741-755.

Teixeira, I.A.M.A., Harter, C.J., Pereira Filho, J.M., Sobrinho, A.G., Resende, K.T., 2015 Mineral requirements for growth and maintenance of F1 Boer x Saanen male kids. J. Anim. Sci. 93, 2349-2356.

Tilahun, M., Kefelegn, K., Abebe, G., Goetsch, A.L., 2014. Feed intake, digestibility, weight gain, and slaughter characteristics influenced by genetic percentage of Boer in goats and Dorper in sheep in the central highlands of Ethiopia. Trop. Anim. Health. Prod. 46, 593-602.

Warner, R.G., Flatt, W.P., Loosli, J.K., 1956. Dietary factors influencing the development of the ruminant stomach. J. Agr. Food Chem. 4, 788-801. 